\title{
Recent progress in the discovery of inhibitors targeting coronavirus proteases
}

\author{
Haofeng Wang, Song Xue, Haitao Yang ${ }^{\bowtie}$, Cheng Chen ${ }^{\bowtie}$ \\ School of Life Sciences, Tianjin University, Tianjin 300072, China
}

Coronaviruses (CoVs) can cause highly prevalent diseases in humans and animals. The fatal outbreak of severe acute respiratory syndrome (SARS) and Middle East respiratory syndrome (MERS) highlights the threat posed by this unique virus subfamily. However, no specific drugs have been approved to treat CoV-associated diseases to date. The CoV proteases, which play pivotal roles in viral gene expression and replication through a highly complex cascade involving the proteolytic processing of replicase polyproteins, are attractive targets for drug design. This review summarizes the recent advances in biological and structural studies, together with the development of inhibitors targeting CoV proteases, particularly main proteases $\left(\mathrm{M}^{\text {pro }} \mathrm{S}\right)$, which could help develop effective treatments to prevent CoV infection.

\section{KEYWORDS coronaviruses; main protease; protease inhibitors}

\section{INTRODUCTION}

Before the outbreak of the severe acute respiratory syndrome (SARS) epidemic worldwide in the winter of 2002 to the summer of 2003, coronaviruses (CoVs) had long been considered to cause merely mild symptoms in humans despite being attributed to severe diseases in animals (Dominguez et al., 2003; Drosten et al., 2003; Franco-Paredes et al., 2003; Kuiken et al., 2003; Rota et al., 2003). The SARS epidemic, caused by the SARS coronavirus (SARS-CoV), resulted in a total of 775 deaths out of 8,273 cases of infection (Dominguez et al., 2003; Franco-Paredes et al., 2003). In 2012, another new $\mathrm{CoV}$ called the Middle East respiratory syndrome coronavirus (MERS-CoV) emerged, which originated from the Middle East (Zaki et al., 2012). According to the World Health Organization, this new CoV has thus far resulted

Received: 29 December 2015, Accepted: 22January 2016,

Published online: 19 February 2016

$\triangle$ Correspondence:

Haitao Yang, Phone: +86-22-27403959, Fax: +86-22-27403902

Email: yanght@tju.edu.cn

ORCID: 0000-0002-1875-3268

Cheng Chen, Phone: +86-22-27403906, Fax: +86-22-27403902

Email: chengchen@tju.edu.cn

ORCID: 0000-0002-2228-2489 in 1,633 cases of infection causing 587 deaths (http:// www.who.int/emergencies/mers-cov/en/). Both SARSand MERS-CoVs have zoonotic origins (Woo et al., 2009; Woo et al., 2012; Chan et al., 2013; Ge et al., 2013; Lu et al., 2015; St John et al., 2015), strongly suggesting that animal CoVs remain a potential threat to humans. However, no specific drugs have been approved to treat $\mathrm{CoV}$-associated diseases to date.

In the wake of the SARS outbreak, in-depth research has revealed multiple aspects of the life cycle of $\mathrm{CoV}$ infection. CoVs mainly take advantage of spike proteins to bind their receptors for attachment to the host cell membrane ( $\mathrm{Ng}$ et al., 2003). Upon entering host cells, CoVs start to release genomic RNA. Subsequent expression of two polyproteins responsible for viral replication and transcription, respectively, requires hijacking of host ribosomes to facilitate translation (Thiel et al., 2003). The two resulting polyproteins are further processed by two viral-encoded proteases into 16 mature nonstructural proteins (nsps): Nsp1, a host gene expression suppressor; nsp2, which functions in interacting with the two host proteins; nsp3, a multi-domain complex; nsp4/nsp6, transmembrane proteins; nsp5, the $\mathrm{M}^{\mathrm{pro}}$; nsp $7 / \mathrm{nsp} 8$, primases; nsp9, a single-stranded RNA-binding protein; nsp12, an RNA-dependent RNA polymerase; nsp13, 5'to-3' RNA helicase/NTPase/RNA 5'-triphosphatase; 
Table 1. Inhibitors targeting papain-like protease $\left(\mathrm{PL}^{\text {Pro }}\right)$ and main protease $\left(\mathrm{M}^{\text {pro }}\right)$.

\begin{tabular}{llll} 
Targets & Inhibitors & Effective/inhibitory concentration & References \\
\hline $\mathrm{PL}^{\text {pro }}$ & $5 \mathrm{c}$ & $9.5 \mu \mathrm{mol} / \mathrm{L}\left(\mathrm{EC}_{50}\right)$ & Baez-Santos et al., 2014 \\
& $8 \mathrm{k}_{1}$ & $1.04 \mu \mathrm{mol} / \mathrm{L}\left(\mathrm{IC}_{50}\right)$ & Liu et al., $2014 ;$ \\
$\mathrm{M}^{\text {pro }}$ & decahydroisoquinolin scaffold 41 & $63 \mu \mathrm{mol} / \mathrm{L}\left(\mathrm{IC}_{50}\right)$ & Shimamoto et al., 2015 \\
& Cbz-TSAVLQ-CN & $1.3-4.6 \mu \mathrm{mol} / \mathrm{L}\left(\mathrm{IC}_{50}\right)$ & Chuck et al., 2014 \\
& $\mathrm{NPI52}$ & $0.02 \mu \mathrm{mol} / \mathrm{L}\left(\mathrm{EC}_{50}\right)$ & Kim et al., 2015 \\
\hline
\end{tabular}

Note: $\mathrm{EC}_{50}$ : the half maximal effective concentration; $\mathrm{IC}_{50}$ : the half maximal inhibitory concentration.

nsp14, 3'-to-5' exoribonuclease; nsp15, uridylate-specific endoribonuclease; and nsp16, 2'-O-methyltransferase (Cornillez-TY et al., 2009; te Velthuis et al., 2012; Ivanov et al., 2004; Narayanan et al., 2008; Snijder et al., 2003; Sutton et al., 2004; Ziebuhr, 2005). These nsps can then assemble into the replication-transcription complex and facilitate viral RNA replication and transcription (Zhao et al., 2013a). Currently, several viral proteins are considered candidate targets for drug development, including proteases, helicases, RdRp, and methyltransferase, which are all involved in the aforementioned viral life cycle (Adedeji and Sarafianos, 2014). Among them, $\mathrm{M}^{\text {pro }}$ is an important target, owing to its essential role in the processing of polyproteins (Ziebuhr et al., $2000)$. In this review, we will focus on recent progress in the development of inhibitors of these proteases, with a particular focus on $\mathrm{M}^{\text {pro }}$ (Table 1).

\section{Papain-like protease}

Papain-like protease ( $\mathrm{PL}^{\mathrm{pro}}$ ) (Figure 1A) exists as a functional domain within the large nsp3, which also encodes a ubiquitin-like fold, an ADP-ribose-1d-phosphatase domain, a SARS-CoV-unique domain, and a transmembrane domain (Lee et al., 2015). PL ${ }^{\text {pro }}$ recognizes a specific site comprising the consensus cleavage sequence LXGG between nsp1/2, nsp2/3 and nsp3/4 (Lee et al., 2015). Proteolytic cleavage of the peptide bond after the glycine residue can result in the release of nsp1, nsp2, and nsp3 from the viral polyproteins, which is a critical step for viral replication (Ziebuhr et al., 2000).

$\mathrm{PL}^{\mathrm{pro}}$ has been found to have deubiquitination and deinterferon stimulated gene-ylation (ISGylation) functions (Chen et al., 2015). This can help the virus to escape the host immune response via the interferon signaling pathway (Baez-Santos et al., 2015). In MERS-CoV, $\mathrm{PL}^{\mathrm{pro}}$ has been reported to protect polyproteins from cleavage through the interferon regulatory factor 3 pathway (Sun et al., 2012). $\mathrm{PL}^{\mathrm{pro}} \mathrm{s}$ from different $\mathrm{CoV}$ species may also vary in substrate specificity (Lee et al., 2015), which may contribute to the difficulty in developing a wide-spectrum drug targeting CoVs. Nonetheless, some molecules have been found to effectively inhibit
$\mathrm{CoV}$ infection, including zinc ion $\left(\mathrm{Zn}^{2+}\right)$ and zinc conjugate inhibitors, which were reported to target PL $^{\text {pro }}$ (Han et al., 2005). However, these inhibitors appear to be unique, because no other metal ions have thus far been found to possess such inhibitory capacity (Baez-Santos et al., 2015). In addition, thiopurine compounds could suppress the activity of $\mathrm{PL}^{\mathrm{pro}} \mathrm{s}$ by covalently binding to the cysteine residue at the active site (Chen et al., 2009). Some natural products have also been found to inhibit $\mathrm{PL}^{\mathrm{pro}}$ activity, including tanshinones (Park et al., 2012b), diarylheptanoids (Park et al., 2012a), and geranylated flavonoids (Cho et al., 2013).

Recently, several crystal structures of SARS-CoV PL ${ }^{\text {pro }}$ in complex with inhibitors have been reported (Ratia et al., 2008; Ghosh et al., 2009; Ghosh et al., 2010; BaezSantos et al., 2014) (Figure 1A-1D). SARS-CoVPL ${ }^{\text {pro }}$ contains two blocking loops, BL1 and BL2, which have proven to be vital in blocking access to the catalytic site (Lee et al., 2015). Upon binding to the BL2 loop, these inhibitors cause a local conformational change and subsequently block access for substrate binding to the catalytic site (Lee et al., 2015).

\section{Main protease}

The CoV genome encodes two overlapping polyproteins designated as ppla and pplab (Mukherjee et al., 2008). The polyproteins are cleaved by viral proteases to yield the 16 mature nsps mentioned above, and assemble into the replication-transcription complex that is essential for viral replication. $\mathrm{M}^{\mathrm{pro}}$ is the key enzyme involved in this proteolysis process (Ziebuhr et al., 2000), and is responsible for cleavage at 11 sites on the polyproteins (Ziebuhr, 2004). Owing to its dominant and indispensable role in polyprotein processing, $\mathrm{M}^{\mathrm{pro}}$ has thus emerged as an important target for anti-CoV drug design.

Many of the inhibitors identified to date, such as peptidomimetic (Ghosh et al., 2007), TG-0205221 (Yang et al., 2006), ketones (Shao et al., 2008), and pyrimidines (Ramajayam et al., 2010), have previously been reviewed in detail (Mukherjee et al., 2011; Zhao et al., 2013a; Zhao et al., 2013b; Adedeji and Sarafianos, 2014). Therefore, we here focus only on the most recent 


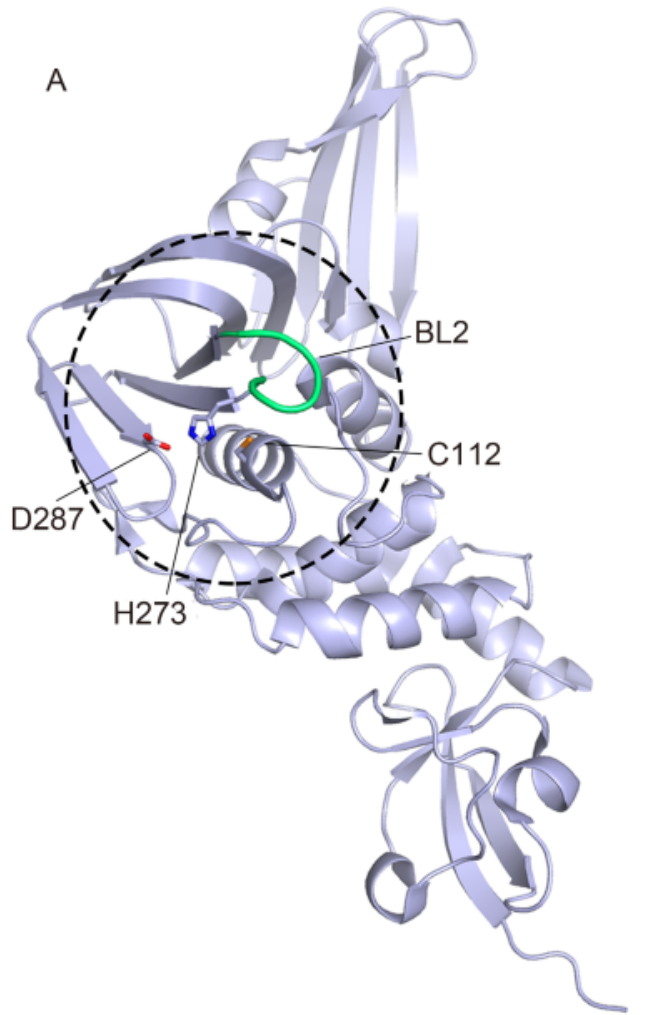

B<smiles>Nc1nc2nc[nH]c2c(=O)[nH]1</smiles>

C<smiles>COc1cc(CNC(=O)C2CCN([C@@H](C)c3cccc4ccccc34)CC2)ccn1</smiles>

D<smiles>C[C@H](c1cccc2ccccc12)N1CCC(C(=O)NCc2ccc3c(c2)OCO3)CC1</smiles>

Figure 1. The structures of CoV PL ${ }^{\text {pro }}$, its inhibitors, and derivatives. (A) Overall structure of SARS-CoV PL ${ }^{\text {pro }}$ (PDB entry 2FE8). The hotspot for inhibitor development is depicted by the dashed circle, with the active site residues (C112, H273, D287) and BL2 loop shown as sticks and a tube, respectively. (B) 6-Thioguanine compound. (C) Methoxypyridine inhibitor 5c. (D) PL ${ }^{\text {pro }}$ inhibitor GRL-0667.

progress in inhibitor and drug discovery.

In the last two years, many research groups have exerted continuous effort on the development of inhibitors targeting CoV $\mathrm{M}^{\mathrm{pro}} \mathrm{s}$ (Figure 2A). Chen et al. and Zhou et al. reported a new class of isatin derivatives as $\mathrm{M}^{\mathrm{pro}}$ inhibitors (Chen et al., 2005; Zhou et al., 2006). Based on their results, Liu et al. started to investigate the potential of using isatin derivatives to design more efficient inhibitors against $\mathrm{CoV} \mathrm{M}^{\mathrm{pro}} \mathrm{s}$ (Liu et al., 2014). In these studies, a series of isatin derivatives were designed, synthesized, and assessed by in vitro enzymatic assays with a fluorogenic substrate peptide. Among them, the 5-sulfonyl isatin derivatives with a carboxamide group substituted by a series of sulfonamide groups showed inhibition against $\mathrm{M}^{\mathrm{pro}}$ at the micromolar range. Assisted by a structure-based lead compound design, the authors effectively optimized the 5-sulfonyl isatin derivatives and obtained an optimal compound named $8 \mathrm{k}_{1}\left(\mathrm{IC}_{50}=1.04\right.$ $\mu \mathrm{mol} / \mathrm{L}$ ) (Figure 2B). By comparisons of different substituted groups, they reached the conclusion that 5 -sulfonyl isatin coupled with methyl at the $\mathrm{N}-1$ position could dramatically promote inhibitory activity, which could facilitate further lead compound development.
Akaji's group reported a novel inhibitor with a decahydroisoquinolin scaffold that could target SARS$\mathrm{CoV} \mathrm{M}^{\text {pro }}$ (Shimamoto et al., 2015) (Figure 2C). Previous studies showed that the hydrophobic interactions at the S2 site are important for substrate/inhibitor binding. This new inhibitor was designed by connecting the substrate-based inhibitor's cyclohexyl group, located at the P2 site, with the $\alpha$-nitrogen atom of the P2 position on the main chain. This approach could maintain the hydrophobic interactions at the S1 and S2 sites, which kept the imidazole and aldehyde groups in the required configuration for respective binding. The authors further synthesized a series of decahydroisoquinolin derivatives, all of which showed moderate but clear inhibitory activities against SARS-CoV $\mathrm{M}^{\text {pro }}$. X-ray crystallographic studies revealed that the decahydroisoquinolin scaffold was inserted into a large S2 pocket, which occupied most of the pocket to hold the terminal aldehyde tightly inside the active site cleft, resulting in the observed inhibitory activity.

Previously, our group investigated the conservation of $\mathrm{CoV} \mathrm{M}^{\text {pro }} \mathrm{s}$ across species. Structural analyses revealed that the substrate-binding pockets of various $\mathrm{CoV} \mathrm{M}^{\mathrm{pro}} \mathrm{s}$ are highly conserved, which led to the concept of "widespectrum inhibitors" for targeting all CoVs. Through a 


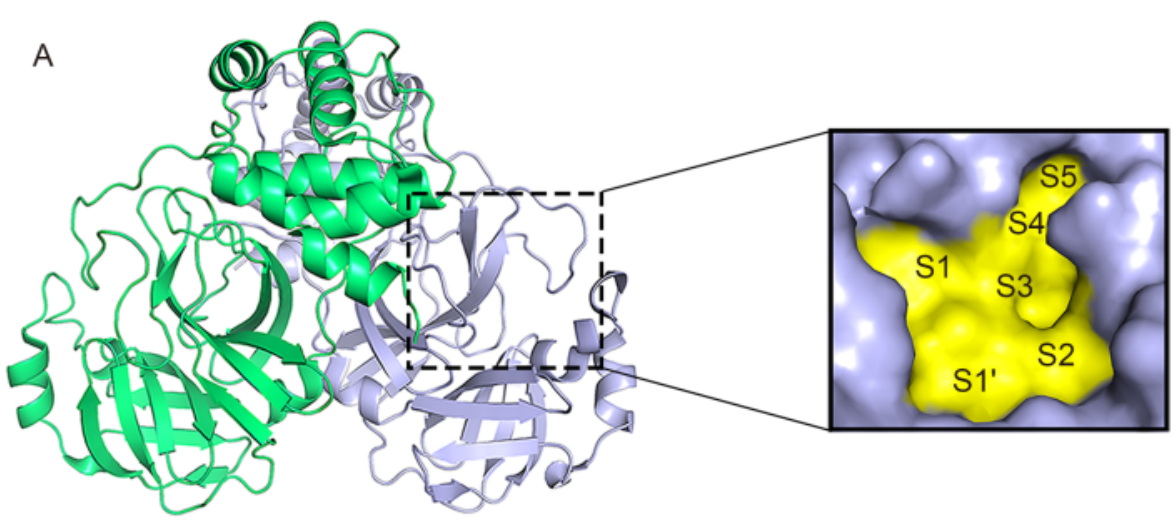

B

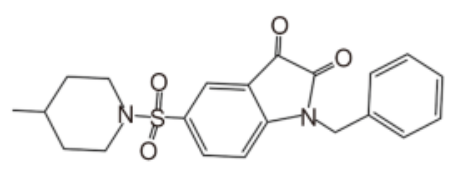

D

C<smiles>O=CC(Cc1c[nH]cn1)NCC1CC2CCCCC2CN1C(=O)c1ccc(Br)cc1</smiles><smiles>Cc1cc(C(=O)NC(C)NC(=O)C(C)C)no1</smiles>

$\mathrm{E}$

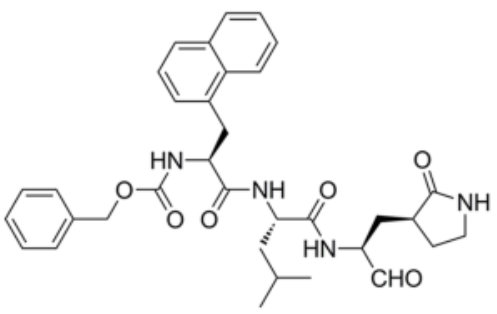

Figure 2. The structures of $\mathrm{CoV} \mathrm{M}^{\text {pro }}$, its inhibitors, and derivatives. (A) Overall structure of SARS-CoV M ${ }^{\text {pro }}$ (PDB entry 1UK3). Two protomers are shown in lime green and light blue, respectively. The substrate-binding pocket is shown in yellow in the inset, with subsites labeled. (B) Compound $8 \mathrm{k}_{1}$ of isatin derivatives. (C) Inhibitor derived from the decahydroisoquinolin scaffold. (D) An irreversible compound N3. (E) Peptidyl compound NPI52.

structure-based drug design, we have identified a lead compound named N3 with potent inhibitory activity against all $\mathrm{M}^{\mathrm{pro}}$ s tested (Figure 2D). Recently, the Wong group analyzed the substrate specificity of $\mathrm{M}^{\text {pro }}$ from the P5 to P3' sites among several CoVs, and found that all $\mathrm{M}^{\mathrm{pro}}$ s have similar substrate specificity. This finding facilitated the design of a broad-spectrum peptidomimetic inhibitor against various $\mathrm{CoV} \mathrm{M}^{\mathrm{pro}}$ s. They identified a new peptidyl compound, Cbz-TSAVLQ-CN, by coupling a nitrile warhead and a carboxybenzyl (Cbz) group to the $\mathrm{C}$-terminus and $\mathrm{N}$-terminus of a peptide, respectively (Chuck et al., 2014). Enzymatic assays revealed that it could inhibit $\mathrm{M}^{\text {pro }} \mathrm{s}$ from six different species of CoVs. The solved crystal structure of the enzyme in complex with this inhibitor indicated that the N-terminal $\mathrm{Cbz}$ protective group could improve the interaction between the inhibitor and the protease. Kim et al. also designed a series of peptidyl compounds targeting feline coronaviruses (FCoV) and feline caliciviruses (FCV) (Kim et al., 2015). They reported that a compound named NPI52 displayed inhibitory activity against FCoV and FCV strains in cell culture (Figure 2E). This inhibitory effect was further confirmed in a mouse model based on liver histopathology analysis.

In addition, we have designed $\mathrm{N} 3$ and zinc ion as dual inhibitors against feline infectious peritonitis virus (FIPV) $\mathrm{M}^{\mathrm{pro}}$. The biochemical data showed that N3 and $\mathrm{Zn}^{2+}$ could serve as an irreversible inhibitor and a noncompetitive inhibitor, respectively. The solved crystal structure of FIPV $\mathrm{M}^{\text {pro }}$ in complex with these two inhibitors demonstrated their potential for synergistic activity to achieve an enhanced inhibitory effect (Wang et al., 2015). These findings provide a new approach in the design of anti-CoV drugs. 
On the other hand, gaining a better understanding of the cleavage mechanism of $\mathrm{CoV} \mathrm{M}^{\text {pro }}$ s could help to provide new directions for the design of inhibitors. Dimerization is an essential step in $\mathrm{M}^{\mathrm{pro}}$ maturation for subsequent catalysis. Shi et al. reported the mechanism of $\mathrm{CoV} \mathrm{M}{ }^{\text {pro }}$ for controlling the dimer-monomer switch (Shi et al., 2008). Specifically, mutation of the residue $\operatorname{Arg} 298$ at the dimer interface was shown to disturb the dimerization of $\mathrm{M}^{\mathrm{pro}}$ (Paasche et al., 2014), which could be reverted via a substrate-induced conformational change. Moreover, structural studies revealed that the establishment of a new intermolecular interaction required domain III composed of a globular cluster of five helices (Anand et al., 2003) to alter its orientation. This suggests that $\mathrm{M}^{\text {pro }}$ should be able to tolerate large conformational changes without loss of enzymatic activity. This further implies that intramolecular communication and regulation exists within the $\mathrm{M}^{\mathrm{pro}}$ structure. Thus, better understanding of the underlying mechanism might aid in structure-based anti-CoV drug design.

Paasche et al. reported substrate binding-induced zwitterion formation at the active site of SARS-CoV $\mathrm{M}^{\mathrm{pro}}$ (Paasche et al., 2014). They discovered that the $\mathrm{Cys}^{-} / \mathrm{His}^{+}$ zwitterionic state is essential for efficient proteolytic activity, which is fostered by substrate binding rather than by inhibitor binding, and enhances its substrate specificity. The free-energy calculations delineated that substrate binding could promote the proton transfer reaction, which reduces the energy between neutral and zwitterionic states. This implies that development of antiviral agents with ability of the substrate to trigger the zwitterionic state may be an alternative approach for drug design.

\section{CONCLUSION}

In the wake of outbreaks of SARS and MERS, CoVs have emerged as life-threatening pathogens for humans. Their zoonotic origin also sends a warning of the potential emergence of new deadly CoVs via interspecies transmission. Thus, many inhibitors have been developed to prevent $\mathrm{CoV}$ infection. However, the problems of toxicity, ability to enter cells, non-specificity, and instability (particularly for peptide-derived inhibitors), among others, are still major hurdles to overcome for these lead compounds. Therefore, further investigation is required to develop an effective treatment to prevent $\mathrm{CoV}$ infection, which will require tackling the problem with multiple approaches.

\section{ACKNOWLEDGMENTS}

This work was supported by the Tianjin University Un- dergraduate Research Foundation, Tianjin UniversityHainan University Collaborative Foundation, National Natural Science Foundation of China (No. 31300150), and Tianjin Marine Science and Technology Program (No. KJXH2014-16).

\section{COMPLIANCE WITH ETHICS GUIDELINES}

The authors declare that they have no conflict of interest. This article does not contain any studies with human or animal subjects performed by any of the authors.

\section{REFERENCES}

Adedeji AO, Sarafianos SG. 2014. Antiviral drugs specific for coronaviruses in preclinical development. Curr Opin Virol, 8: $45-53$.

Anand K, Ziebuhr J, Wadhwani P, Mesters JR, Hilgenfeld R. 2003.Coronavirus main proteinase (3CLpro) structure: basis for design of anti-SARS drugs. Science, 300: 1763-1767.

Baez-Santos YM, Barraza SJ, Wilson MW, Agius MP, Mielech AM, Davis NM, Baker SC, Larsen SD, Mesecar AD. 2014. Xray structural and biological evaluation of a series of potent and highly selective inhibitors of human coronavirus papain-like proteases. J Med Chem, 57: 2393-2412.

Baez-Santos YM, St John SE, Mesecar AD. 2015. The SARScoronavirus papain-like protease: structure, function and inhibition by designed antiviral compounds. Antiviral Res, 115: 21-38.

Chan JF, To KK, Tse H, Jin DY, Yuen KY. 2013. Interspecies transmission and emergence of novel viruses: lessons from bats and birds. Trends Microbiol, 21: 544-555.

Chen LR, Wang YC, Lin YW, Chou SY, Chen SF, Liu LT, Wu YT, Kuo CJ, Chen TS, Juang SH. 2005. Synthesis and evaluation of isatin derivatives as effective SARS coronavirus $3 \mathrm{CL}$ protease inhibitors. Bioorg Med Chem Lett, 15: 3058-3062.

Chen X, Chou CY, Chang GG. 2009. Thiopurine analogue inhibitors of severe acute respiratory syndrome-coronavirus papainlike protease, a deubiquitinating and deISGylating enzyme. Antivir Chem Chemother, 19: 151-156.

Chen Y, Savinov SN, Mielech AM, Cao T, Baker SC, Mesecar AD. 2015. X-ray Structural and Functional Studies of the Three Tandemly Linked Domains of Non-structural Protein 3 (nsp3) from Murine Hepatitis Virus Reveal Conserved Functions. J Biol Chem, 290: 25293-25306.

Cho JK, Curtis-Long MJ, Lee KH, Kim DW, Ryu HW, Yuk HJ, Park KH. 2013. Geranylated flavonoids displaying SARS-CoV papain-like protease inhibition from the fruits of Paulownia tomentosa. Bioorg Med Chem, 21: 3051-3057.

Chuck CP, Ke ZH, Chen C, Wan DC, Chow HF, Wong KB. 2014. Profiling of substrate-specificity and rational design of broadspectrum peptidomimetic inhibitors for main proteases of coronaviruses. Hong Kong Med J, 20 Suppl 4: 22-25.

Cornillez-Ty CT, Liao L, Yates JR, 3rd, Kuhn P, Buchmeier MJ. 2009. Severe acute respiratory syndrome coronavirus nonstructural protein 2 interacts with a host protein complex involved in mitochondrial biogenesis and intracellular signaling. J Virol, 83: 10314-10318.

Dominguez A, Gudiol F, Pumarola T, Salleras L. 2003. Severe acute respiratory syndrome epidemics: the end or a hiatus of the epidemic?. Med Clin (Barc), 121: 340-346. (In Spanish) 
Drosten C, Gunther S, Preiser W, van der Werf S, Brodt HR, Becker S, Rabenau H, Panning M, Kolesnikova L, Fouchier RA, Berger A, Burguiere AM, Cinatl J, Eickmann M, Escriou N, Grywna K, Kramme S, Manuguerra JC, Muller S, Rickerts V, Sturmer M, Vieth S, Klenk HD, Osterhaus AD, Schmitz H, Doerr HW. 2003. Identification of a novel coronavirus in patients with severe acute respiratory syndrome. N Engl J Med, 348: 1967-1976.

Franco-Paredes C, Kuri-Morales P, Alvarez-Lucas C, Palacios-Zavala $\mathrm{E}$, Nava-Frias $\mathrm{M}$, Betancourt-Cravioto $\mathrm{M}$, Santos-Preciado JI, Tapia-Conyer R. 2003. Severe acute respiratory syndrome: a global overview of the epidemic. Salud Publica Mex, 45: 211-220. (In Spanish)

Ge XY, Li JL, Yang XL, Chmura AA, Zhu G, Epstein JH, Mazet JK, Hu B, Zhang W, Peng C, Zhang YJ, Luo CM, Tan B, Wang N, Zhu Y, Crameri G, Zhang SY, Wang LF, Daszak P, Shi ZL. 2013. Isolation and characterization of a bat SARS-like coronavirus that uses the ACE2 receptor. Nature, 503: 535-538.

Ghosh AK, Takayama J, Aubin Y, Ratia K, Chaudhuri R, Baez Y, Sleeman K, Coughlin M, Nichols DB, Mulhearn DC, Prabhakar BS, Baker SC, Johnson ME, Mesecar AD. 2009. Structurebased design, synthesis, and biological evaluation of a series of novel and reversible inhibitors for the severe acute respiratory syndrome-coronavirus papain-like protease. J Med Chem, 52: 5228-5240.

Ghosh AK, Takayama J, Rao KV, Ratia K, Chaudhuri R, Mulhearn DC, Lee H, Nichols DB, Baliji S, Baker SC, Johnson ME, Mesecar AD. 2010. Severe acute respiratory syndrome coronavirus papain-like novel protease inhibitors: design, synthesis, protein-ligand X-ray structure and biological evaluation. J Med Chem, 53: 4968-4979.

Ghosh AK, Xi K, Grum-Tokars V, Xu X, Ratia K, Fu W, Houser KV, Baker SC, Johnson ME, Mesecar AD. 2007. Structurebased design, synthesis, and biological evaluation of peptidomimetic SARS-CoV 3CLpro inhibitors. Bioorg Med Chem Lett, 17: 5876-5880.

Han YS, Chang GG, Juo CG, Lee HJ, Yeh SH, Hsu JT, Chen X. 2005. Papain-like protease 2 (PLP2) from severe acute respiratory syndrome coronavirus (SARS-CoV): expression, purification, characterization, and inhibition. Biochemistry, 44: 1034910359.

Ivanov KA, Thiel V, Dobbe JC, van der Meer Y, Snijder EJ, Ziebuhr J. 2004.Multiple enzymatic activities associated with severe acute respiratory syndrome coronavirus helicase. J Virol, 78: 5619-5632.

Kim Y, Shivanna V, Narayanan S, Prior AM, Weerasekara S, Hua DH, Kankanamalage AC, Groutas WC, Chang KO. 2015. Broad-spectrum inhibitors against 3C-like proteases of feline coronaviruses and feline caliciviruses. J Virol, 89: 4942-4950.

Kuiken T, Fouchier RAM, Schutten M, Rimmelzwaan GF, van Amerongen G, van Riel D, Laman JD, de Jong T, van Doornum G, Lim W, Ling AE, Chan PKS, Tam JS, Zambon MC, Gopal R, Drosten C, van der Werf S, Escriou N, Manuguerra J-C, Stöhr K, Peiris JSM, Osterhaus ADME. 2003. Newly discovered coronavirus as the primary cause of severe acute respiratory syndrome. Lancet, 362: 263-270.

Lee H, Lei H, Santarsiero BD, Gatuz JL, Cao S, Rice AJ, Patel K, Szypulinski MZ, Ojeda I, Ghosh AK, Johnson ME. 2015. Inhibitor recognition specificity of MERS-CoV papain-like protease may differ from that of SARS-CoV. ACS Chem Biol, 10: $1456-1465$.

Liu W, Zhu HM, Niu GJ, Shi EZ, Chen J, Sun B, Chen WQ, Zhou HG, Yang C. 2014. Synthesis, modification and docking studies of 5-sulfonyl isatin derivatives as SARS-CoV 3C-like protease inhibitors. Bioorg Med Chem, 22: 292-302.
Lu G, Wang Q, Gao GF. 2015. Bat-to-human: spike features determining 'host jump' of coronaviruses SARS-CoV, MERS$\mathrm{CoV}$, and beyond. Trends Microbiol, 23: 468-478.

Mukherjee P, Desai P, Ross L, White EL, Avery MA. 2008. Structure-based virtual screening against SARS-3CL(pro) to identify novel non-peptidic hits. Bioorg Med Chem, 16: 4138-4149.

Mukherjee P, Shah F, Desai P, Avery M. 2011. Inhibitors of SARS-3CLpro: virtual screening, biological evaluation, and molecular dynamics simulation studies. J Chem Inf Model, 51: 1376-1392.

Narayanan K, Huang C, Lokugamage K, Kamitani W, Ikegami T, Tseng CT, et al. 2008. Severe acute respiratory syndrome coronavirus nsp1 suppresses host gene expression, including that of type I interferon, in infected cells. J Virol. 82: 4471-4479.

$\mathrm{Ng}$ ML, Tan SH, See EE, Ooi EE, Ling AE. 2003. Early events of SARS coronavirus infection in vero cells. Journal of medical virology.71: 323-331.

Paasche A, Zipper A, Schafer S, Ziebuhr J, Schirmeister T, Engels B. 2014. Evidence for substrate binding-induced zwitterion formation in the catalytic Cys-His dyad of the SARS-CoV main protease. Biochemistry, 53: 5930-5946.

Park JY, Jeong HJ, Kim JH, Kim YM, Park SJ, Kim D, Park KH, Lee WS, Ryu YB. 2012a. Diarylheptanoids from Alnus japonica inhibit papain-like protease of severe acute respiratory syndrome coronavirus. Biol Pharm Bull, 35: 2036-2042.

Park JY, Kim JH, Kim YM, Jeong HJ, Kim DW, Park KH, Kwon HJ, Park SJ, Lee WS, Ryu YB. 2012b. Tanshinones as selective and slow-binding inhibitors for SARS-CoV cysteine proteases. Bioorg Med Chem, 20: 5928-5935.

Ramajayam R, Tan KP, Liu HG, Liang PH. 2010. Synthesis, docking studies, and evaluation of pyrimidines as inhibitors of SARS-CoV 3CL protease. Bioorg Med Chem Lett, 20: 3569-3572.

Ratia K, Pegan S, Takayama J, Sleeman K, Coughlin M, Baliji S, Chaudhuri R, Fu W, Prabhakar BS, Johnson ME, Baker SC, Ghosh AK, Mesecar AD. 2008. A noncovalent class of papainlike protease/deubiquitinase inhibitors blocks SARS virus replication. Proc Natl Acad Sci U S A, 105: 16119-16124.

Rota PA, Oberste MS, Monroe SS, Nix WA, Campagnoli R, Icenogle JP, Penaranda S, Bankamp B, Maher K, Chen MH, Tong S, Tamin A, Lowe L, Frace M, DeRisi JL, Chen Q, Wang D, Erdman DD, Peret TC, Burns C, Ksiazek TG, Rollin PE, Sanchez A, Liffick S, Holloway B, Limor J, McCaustland K, Olsen-Rasmussen M, Fouchier R, Gunther S, Osterhaus AD, Drosten C, Pallansch MA, Anderson LJ, Bellini WJ. 2003. Characterization of a novel coronavirus associated with severe acute respiratory syndrome. Science, 300: 1394-1399.

Shao YM, Yang WB, Kuo TH, Tsai KC, Lin CH, Yang AS, Liang PH, Wong CH. 2008. Design, synthesis, and evaluation of trifluoromethyl ketones as inhibitors of SARS-CoV 3CL protease. Bioorg Med Chem, 16: 4652-4660.

Shi J, Sivaraman J, Song J. 2008. Mechanism for controlling the dimer-monomer switch and coupling dimerization to catalysis of the severe acute respiratory syndrome coronavirus 3C-like protease. J Virol, 82: 4620-4629.

Shimamoto Y, Hattori Y, Kobayashi K, Teruya K, Sanjoh A, Nakagawa A, Yamashita E, Akaji K. 2015. Fused-ring structure of decahydroisoquinolin as a novel scaffold for SARS 3CL protease inhibitors. Bioorg Med Chem, 23: 876-890.

Snijder EJ, Bredenbeek PJ, Dobbe JC, Thiel V, Ziebuhr J, Poon LL, et al. 2003. Unique and conserved features of genome and proteome of SARS-coronavirus, an early split-off from the coronavirus group 2 lineage. J Mol Biol, 331: 991-1004.

St John SE, Tomar S, Stauffer SR, Mesecar AD. 2015. Targeting 
zoonotic viruses: Structure-based inhibition of the 3C-like protease from bat coronavirus HKU4--The likely reservoir host to the human coronavirus that causes Middle East Respiratory Syndrome (MERS). Bioorg Med Chem, 23: 6036-6048.

Sun L, Xing Y, Chen X, Zheng Y, Yang Y, Nichols DB, Clementz MA, Banach BS, Li K, Baker SC, Chen Z. 2012. Coronavirus papain-like proteases negatively regulate antiviral innate immune response through disruption of STING-mediated signaling. PLoS One, 7: e30802.

Sutton G, Fry E, Carter L, Sainsbury S, Walter T, Nettleship J, et al. 2004. The nsp9 replicase protein of SARS-coronavirus, structure and functional insights. Structure, 12: 341-353.

te Velthuis AJ, van den Worm SH, Snijder EJ. 2012. The SARScoronavirus $n s p 7+n s p 8$ complex is a unique multimeric RNA polymerase capable of both de novo initiation and primer extension. Nucleic acids research, 40: 1737-1747.

Thiel V, Ivanov K A, Putics A, Hertzig T, Schelle B, Bayer S, Weissbrich B, Snijder E J, Rabenau H, Doerr H W, Gorbalenya A E, Ziebuhr J. 2003. Mechanisms and enzymes involved in SARS coronavirus genome expression. J Gen Virol, 84: 2305-2315.

Wang F, Chen C, Liu X, Yang K, Xu X, Yang H. 2015. The crystal structure of feline infectious peritonitis virus main protease in complex with synergetic dual inhibitors. J Virol. doi: 10.1128/JVI.02685-15.

Woo PC, Lau SK, Huang Y, Yuen KY. 2009. Coronavirus diversity, phylogeny and interspecies jumping. Exp Biol Med (Maywood), 234: 1117-1127.

Woo PC, Lau SK, Lam CS, Lau CC, Tsang AK, Lau JH, Bai R, Teng JL, Tsang CC, Wang M, Zheng BJ, Chan KH, Yuen KY. 2012. Discovery of seven novel Mammalian and avian coronav- iruses in the genus deltacoronavirus supports bat coronaviruses as the gene source of alphacoronavirus and betacoronavirus and avian coronaviruses as the gene source of gammacoronavirus and deltacoronavirus. J Virol, 86: 3995-4008.

Yang S, Chen SJ, Hsu MF, Wu JD, Tseng CT, Liu YF, Chen HC, Kuo CW, Wu CS, Chang LW, Chen WC, Liao SY, Chang TY, Hung HH, Shr HL, Liu CY, Huang YA, Chang LY, Hsu JC, Peters CJ, Wang AH, Hsu MC. 2006. Synthesis, crystal structure, structure-activity relationships, and antiviral activity of a potent SARS coronavirus 3CL protease inhibitor. J Med Chem, 49: 4971-4980.

Zaki AM, van Boheemen S, Bestebroer TM, Osterhaus AD, Fouchier RA. 2012. Isolation of a novel coronavirus from a man with pneumonia in Saudi Arabia. N Engl J Med, 367: 1814-1820.

Zhao Q, Weber E, Yang H. 2013a. Drug targets for rational design against emerging coronaviruses. Infect Disord Drug Targets, 13: $116-127$

Zhao Q, Weber E, Yang H. 2013b. Recent developments on coronavirus main protease/3C like protease inhibitors. Recent Pat Antiinfect Drug Discov, 8: 150-156.

Zhou L, Liu Y, Zhang W, Wei P, Huang C, Pei J, Yuan Y, Lai L. 2006. Isatin compounds as noncovalent SARS coronavirus 3Clike protease inhibitors. J Med Chem, 49: 3440-3443.

Ziebuhr J, 2004. Molecular biology of severe acute respiratory syndrome coronavirus. Curr Opin Microbiol, 7: 412-419.

Ziebuhr J. 2005.The coronavirus replicase. Curr Top Microbiol Immunol, 287: 57-94.

Ziebuhr J, Snijder EJ, Gorbalenya AE. 2000. Virus-encoded proteinases and proteolytic processing in the Nidovirales. J Gen Virol, 81: 853-879. 